\title{
Taxation and budgetary policies in the western Balkans
}

\begin{abstract}
Today, the governments of the western Balkan countries are confronted with huge financing problems due to very low employment rates, high levels of undeclared work, low financial discipline and a lack of equity and efficiency in tax matters. The consequence is that these governments depend, to a certain degree, on the support of the European and international financial institutions to fix their budgets. Such a situation is unsustainable in the long run. The main aim of this article, which is drawn from a substantial comparative report into the issue, is to examine budgetary and taxation policies in individual European countries, with a special focus on the western Balkans in the context of its road to EU membership, from the viewpoint of equity, efficiency and sustainability. We examine how good governance in tax matters and the fight against tax fraud and tax evasion can help to raise domestic revenue, while we also highlight the responses of trade unions in the region as regards tax reforms particularly with regard to workers and the labour market.
\end{abstract}

Keywords: tax policy, governance, austerity, tax rates, wealth, social contributions, reform, trade unions, informal economy

\section{Taxation policy objectives}

Adequate tax revenues are necessary to guarantee democracy, public order and the operation of the legal system. However, modern taxation should be more than just a source of revenue for the operation of the state: taxation must also enable the public authorities to contribute actively to the pursuit of economic, social and environmental policy goals. A proper road network; an efficient public transport system; a modern health service and hospital provision; an appropriate system of education; protection of the environment; and active employment and vocational training policies all require the injection of large doses of public finance.

At the same time, taxation is an important springboard for a redistribution of income among citizens. Ensuring solidarity and social cohesion in society requires major social transfers and taxation has a significant role to play, too. Taxation is also an instrument for influencing human behaviour, e.g. in the environmental field or related to active ageing (work bonus).

Nevertheless, taxation policy should not be an instrument of competition between governments as a means of attracting investment. A policy of this kind leads to tax dumping and undermines the basic goals of tax policy.

Three of the most important prerequisites for the achievement of these tax policy objectives are: an efficient management of public resources; an efficient operation of 
public services; and the provision of quality services for the consumers of these services.

\section{Principles of taxation policy}

Taxation policies must meet a series of important criteria.

First of all, taxation should be a subject for concertation with the social partners at all levels, including at European level. In particular view of the heavy tax burden borne by them, workers wish to have their say in defining tax policy.

Secondly, taxation should be conceived in a fair manner so as to ensure tax equity. Currently, labour income is too heavily taxed in comparison with consumption and income from capital. Furthermore, salaried labour is too heavily taxed in comparison with self-employed labour; this is a result, in particular, of the considerable leeway enjoyed by the self-employed and members of the professions in determining their taxable earnings.

Thirdly, closely linked to the question of tax equity is the question of tax efficiency. It is not enough that the tax system should be equitably devised: it must also operate efficiently, while the levying of taxes must be guaranteed by procedures that actually work.

Fourthly, taxation must also be functional, i.e. the tax measures must be conceived in such a way that they lead to the achievement of the goals pursued.

Fifthly, the tax system must be simple and transparent, and easy to administer, enabling the tax authorities to concentrate their efforts on the work of checking and control. Transparency must be such as to enable taxpayers to understand the logic and mechanisms of the system.

Sixthly, the tax system must also be consistent with the other policies conducted.

Seventhly, taxation should respect the principles of specificity and subsidiarity; that is, the different levels of government should each be given their own powers to levy taxes in accordance with their responsibilities and the nature of the problems. Taxes which directly affect, or are directly affected by, the behaviour of other member states should be the subject of basic rules agreed at European or international level. Examples of this kind of taxes include corporation taxes and taxes on income from savings (interests, dividends).

\section{The importance of good public governance in tax and budgetary matters}

The design and successful implementation of a sustainable tax system requires sound and stable public budget governance practices.

According to Alex Matheson (OECD), good governance refers, above all, to the settings within which public policies are decided and executed, and not to those public policies per se.

Effective public governance should provide coherence between different policy objectives, as well as an environment in which people are treated fairly and equitably. Meanwhile, good public governance in the field of public budgeting and financial management requires: 
a) fiscal transparency, meaning an open fiscal process (with, for example, information on the de-budgeting of expenditure or on the mandates given to sub-central government), and information on the economic assumptions used to construct the budget (often governments use overly-optimistic economic growth estimates)

b) accountability, meaning independent controls on expenditure, financial management and respect for procedures (e.g. public procurement) in order to avoid the abuse of power by individuals or groups

c) responsiveness, meaning the capacity to respond in a flexible way to unforeseen national or international changes (e.g. lower than expected economic growth)

d) future orientation, meaning that future costs (public debt, the costs of ageing populations) are taken fully into account and that the future fiscal consequences of current policies (e.g. in the field of public employment) and behaviour (e.g. environmental degradation) are recognised in order not to overburden future generations.

Good governance in the field of budgets and taxation policies - at the political, institutional and bureaucratic level - can only work if there is a supportive culture for rule-compliant behaviour oriented towards the public interest. However, achieving this culture requires a lengthy, continuous and gradual process of change in attitudes and values. In the absence of such a culture, there will be no trust in governments and it will be difficult to convince citizens to pay the taxes due.

\section{The EU context}

Europe has been faced with a financial and economic crisis since 2008. What started as a banking crisis soon became a fiscal crisis. In the beginning, most EU governments mobilised considerable financial resources through economic stimulus programmes (e.g. public investment) and automatic stabilisers (e.g. social welfare) in the attempt to establish counter-cyclical policies. Social expenditure increased whilst revenues (taxes and social contributions) diminished. Public budgets came under high fiscal stress: deficits grew and debts exploded.

In 2009 , the budget deficit was $6.8 \%$ on average across the EU-27 $(6.3 \%$ in the Eurozone) while in 2010 the deficit was, on average, 6.4\% in the EU-27 (and 6\% in the Eurozone). Between 2007 and 2012, public debt (as a percentage of GDP) increased by $24.3 \%$ on average in the EU-27 (and by $22.3 \%$ in the Eurozone).

For 2013, the European Commission expected the average debt rate in the Eurozone to increase to $95 \%$ of GDP.

The EU (together with the ECB and the IMF) reacted by granting aid to countries in difficulties (via the European Financial Stability Facility - the EFSF - and the future European Stability Mechanism (ESM) and, in particular, by the introduction of new institutions of European economic governance (the European Semester; the six pack; the Euro Plus Pact; and the Treaty on Stability, Co-ordination and Governance) which increased European supervision of national economic and fiscal developments.

Of these institutions, the European Semester aims at the ex ante co-ordination of national economic and labour market policies; and the Euro Plus Pact is intended to improve competitiveness and employment, public budgets, the financial situation of 
social security systems and the stability of the financial sector. The Treaty on Stability, Co-ordination and Governance is known as the European Fiscal Compact.

This inter-governmental treaty, concluded outside the EU legal framework, was signed by 25 EU member states (excepting the UK and Czech Republic) and was implemented as from 1 January 2013. This treaty introduces the 'golden rule' of the balanced budget.

Following the new European agenda, oriented towards fiscal consolidation, ${ }^{1}$ the stimulus policies were replaced by austerity programmes the size of which was estimated at $0.9 \%$ of GDP in the EU-27, both in 2010 and 2011 (Theodoropoulou and Watt, 2011).

Most of the fiscal adjustment programmes, especially in eastern and southern European countries and in Ireland, focus on public spending reductions in investment, social welfare, health and unemployment benefits, pensions, public sector employment and wages; and on the increase of revenues, mainly via a rise in consumption taxes but also via higher personal and corporate income taxes, less tax expenditure and improvements in tax compliance (Bieling, H-J, 2012).

The first experiences with the European Semester indicate an acceleration of public deficit reductions (from -6.8\% GDP in 2009 to $-3.8 \%$ in 2012 in the EU-27) and an increase in the effective retirement age. The consequence of austerity packages and falling investment and growth rates is that the pressure on labour markets has increased: unemployment rates went up from $7.1 \%$ in 2008 to $9.0 \%$ in 2009 (average across the EU-27); in the Eurozone, the figures were $7.6 \%$ in 2008 and $9.6 \%$ in 2009. For 2013, the European Commission expects a further increase to $11.8 \%$ in the Eurozone. Unemployment is especially dramatic amongst young and poorly-qualified workers.

Given the further deepening of the economic crisis, European Commissioner Olli Rehn wrote in mid-February 2013 to finance ministers in the Eurozone announcing that the rebalancing of their budgets may proceed more slowly than originally planned. This is also a modest concession to trade unions who have, for years, criticised the quasiunilateral austerity approach of the EU and governments in the fight against the crisis. In contrast, the trade unions have argued since the beginning for a more balanced approach which builds in room for investment in economic growth.

\section{Policy conclusions and recommendations}

The tax systems in EU member states have more differences than similarities. Differences persist not only concerning total tax revenues, but also concerning the tax structure, tax rates and the definitions of the tax base. The fifteen 'old' member states rely, on average, much more on direct taxes than the thirteen 'new' ones which rely more on indirect taxes. Even for those taxes where the EU has managed a certain degree of harmonisation concerning the tax base and tax rates (VAT, excise duties), differences remain. Especially in the field of direct taxation, as regards corporate and other capital taxes in particular, the EU has made a lot of proposals but has achieved hardly any progress towards a common tax policy. The fundamental reason for this state of play is that tax policy decisions in the EU require unanimity in the Council of Ministers;

1 Defined as concrete policies which are aimed at reducing government deficit and debt accumulation. 
while governments tend to consider taxes (and social protection), and in particular corporate taxes, to be an instrument of national economic policy.

In the absence of pan-European harmonisation in the field of corporate and other capital taxes, and of strong international co-operation between the tax authorities within the framework of the OECD, tax competition and tax dumping, tax evasion and tax fraud will continue. Governments should realise that, without international regulation and co-operation, they will all be losers in the end. Recently, there have been indications inside the EU, the OECD and the G20 that action will be taken in order to strengthen international co-operation in order to reduce international tax evasion and to make sure that international companies pay their share of the tax burden. It cannot be that bilateral agreements or EU directives intended to avoid the double taxation of company profits end up producing no taxation at all.

In the meantime, national governments can do much themselves to implement the principles of good public governance in budgetary and tax matters. The better the governance, the higher the confidence in government and the greater the willingness of people and companies to pay taxes. When people get a fair return in public services and social benefits, they will be willing to pay the price for that. If, on the contrary, they have the impression that their money is not properly spent, they will be reluctant to contribute.

From a social point of view, direct taxes should be privileged over indirect taxes. Taxation of capital income should be brought closer in line with the taxation of labour income. Higher effective capital taxes on big international companies and on personal capital income, together with environmental taxes and a more efficient levy of VAT, could help to reduce the tax on labour.

As far as companies are concerned, this can be done in the following ways:

- setting normal corporate tax rates on a broad tax base

- simplifying rules and procedures

- taxing capital gains realised on the sale of companies

- keeping an eye on cross-border income flows (within OECD transfer pricing guidelines), especially to tax havens

- regularly reviewing companies' accounts by tax authorities and independent auditors

- concluding bilateral tax agreements with other countries

- imposing proportionate penalties in the case of tax fraud

- avoiding overly-generous special tax regimes.

SMEs should be awarded reduced tax rates.

As far as personal capital income is concerned, recurring and socially-corrected taxes can be levied on the income from property (houses, apartments, land) and from current assets (interest and dividends from bonds/shares). Transaction taxes and capital gains taxes on property can also be implemented. Inheritance taxes, where they exist, should be progressive within reasonable limits and should also be non-discriminatory.

As for the taxation of labour income, a flat rate tax is not fair because it violates the basic principle that 'the broadest shoulders should bear the heaviest burden'. Labour income should be taxed according to a progressive scale, with a basic tax-free al- 
lowance. Tax allowances should also be foreseen for professional expenditure; while limited tax credits can be awarded in respect of social or environmental objectives (e.g. mortgages; bonuses for older workers who are in work up to the legal retirement age; energy-saving investments; etc.). For non-active partners, splitting and the separate taxation of labour income (and of extra-legal pension capital) can be important. For dependant children, most governments offer tax relief in addition to child allowances. In place of these reliefs, however, increased social transfers could be envisaged which would make financial support for children more visible. The same principle could be applied to eco-investments.

Tax equity should be guaranteed between all professional groups, while abuses of self-employed status and of company statutes should be prevented. The double taxation of frontier workers should be avoided. And, in order to protect workers' standards of living, regular indexation or the adjustment of tax scales is necessary.

Concerning indirect taxation, and in particular consumption taxes, these should be conceived as a regulatory instrument to influence production and consumption, and to promote qualitative and sustainable economic growth as well as a healthy environment and way of life. Environmental taxes on energy, transport and pollution can be introduced or developed in order to reduce the tax on labour: Sweden has applied such a transfer with success. For reasons of social justice, a certain progressivity should be applied to VAT taxes: essential products and services should be taxed at a lower rate, whilst luxury products should be taxed at a higher rate or be subject to a special luxury tax. In order to protect the living standards of the weakest groups in society, care must be taken to ensure that indirect taxes do not become too predominant in national tax systems.

Turning to social security contributions, these should be high enough to guarantee the adequacy and the sustainability of statutory social benefits, taking into account the ageing of societies. Higher social benefits can be taxed at a reduced rate while the lowest benefits should be tax-free.

In order to increase the effectiveness of the tax system, and also for reasons of social justice, tax evasion and tax fraud has to be tackled. Different measures can contribute to improved tax collection and increased compliance, such as:

- improving the capacity of the tax administration (capacity building)

- investing in the recruitment and training, and the modern equipment, of tax and social security inspectors

- regularly reviewing company accounts and banks (as from 2015, EU banks will be obliged to report their benefits and the taxes they have paid)

- paying all salaries and bonuses into bank accounts

- paying all commercial transactions above $€ 1000$ via bank accounts (cf. Italy)

- promoting declared work via tax incentives (e.g. the tax deductability of certain goods and services) and better informing workers on the long-term benefits of declared work (e.g. a decent pension)

- data mining, data matching and data sharing: organising the linking of different databases, e.g. between declared income and data on spending via credit cards (cf. Italy); between the employment register and social security funds; and between declared income and the registration of cars, apartments, etc. 
- obliging the registration of hired workers before they start to work

- establishing a central register of all bank accounts and reviewing bank accounts in cases of the indications of tax fraud

- tightly controlling transactions in certain sensitive economic niches: antiques; art; gold; and jewellery

- introducing electronic cash registers in the catering industry

- including in annual tax declaration forms a question asking if the person has a bank account or insurance abroad

- regularising and providing amnesty possibilities concerning the repatriation of capital, with reasonable financial penalties

- introducing mutual and automatic information exchange agreements with foreign tax authorities on the income of non residents.

Taxation and budgetary policies in the countries of the western Balkans

Bosnia and Herzegovina ${ }^{2}$

Current situation

There are three legal and economic systems in Bosnia and Herzegovina $(\mathrm{BiH})$ : Republika Srpska; Federation of BiH; and Brčko District.

The taxation system in $\mathrm{BiH}$ is based on legislation adopted at different levels of authority and decision-making: BiH; entity - Republika Srpska (RS) and Federation of $\mathrm{BiH}(\mathrm{FBiH})$, and Brčko District; cantons within $\mathrm{FBiH}$; and municipalities in both $\mathrm{FBiH}$ and $\mathrm{RS}$.

The basic division of taxes in $\mathrm{BiH}$ is as follows:

- indirect taxes (VAT, customs duties and excise duties) are regulated at the $\mathrm{BiH}$ level

- direct taxes (profit tax; income tax; contributions to pensions and disability, health care and unemployment insurance, including child care contributions in RS; property tax, etc.) are regulated at the level of the entities and Brčko District.

Indirect taxes are paid to a single account at the level of $\mathrm{BiH}$ and are distributed between the entities (RS and $\mathrm{FBiH}$ ) and Brčko District in line with the law on payment to a single account and distribution of revenues. VAT has been in force in $\mathrm{BiH}$ as from 1 January 2006, with one rate: $17 \%$.

Direct taxes are regulated at the level of RS, FBIH and Brčko District based on legislation: across all three, rates of profit tax are $10 \%$.

In $\mathrm{BiH}$, there are three systems for the payment of mandatory social contributions, which are partly harmonised, yet not identical:

- RS applies its Law on contributions, based on which the cumulative contribution rate is $33 \%$ of gross salary (contributions to pensions and disability insurance are $18.5 \%$, health care insurance takes $12 \%$, unemployment insurance $1.0 \%$ and child protection $1.5 \%$ ). The Law on income tax sets down an income tax rate of $10 \%$,

2 The first version of this section of the report was drafted by Bojan Marković, economist in SSRS; later adapted and updated by Božana Radošević, KSBiH / SSRS economic expert. 
with the gross salary reduced by one-third in respect of social insurance contributions

- the FBiH Law on contributions sets down a cumulative contribution rate of $31 \%$ from gross salary (pensions and disability insurance 17\%, health care insurance $12.5 \%$ and unemployment insurance $1.5 \%$ ) although contributions are also paid by the employer at a rate of $10.5 \%$ from gross salary $(6 \%$ for pensions and disability insurance, $4 \%$ for heath care insurance and $0.5 \%$ for unemployment insurance). The Law on income tax identifies an income tax rate of $10 \%$, with the gross salary reduced in respect of social insurance contributions by $31 \%$ and additionally by an annual $3600 \mathrm{KM}(€ 1837)$ in respect of a personal allowance

- in accordance with the Law on income tax in Brčko District, the tax rate is $10 \%$, with gross salary also reduced in respect of social insurance contributions, where the cumulative contribution rate is $30.5 \%$ (pensions and disability insurance $17 \%$, health care $12 \%$ and unemployment $1.5 \%$ ). If the employee is registered with the Fund for Pension and Disability Insurance of $\mathrm{FBiH}$, an additional 6\% contribution in respect of pensions and disability insurance is paid by the employer on the basis of gross salary. If the employee is registered with the Fund for Pensions and Disability Insurance of RS, the cumulative contribution rate for social insurance is $31.5 \%$ (pensions and disability $18 \%$, health care $12 \%$ and unemployment $1.5 \%$ ). All employees and residents, on the determination of the tax basis, are entitled to a personal allowance deduction of $3600 \mathrm{KM}(€ 1837)$ annually.

In 2012, the net revenue from indirect taxes at the level of $\mathrm{BiH}$ amounted to $19 \%$ of the BiH GDP. This amount was distributed according to the legally-agreed coefficients between the entities ( $\mathrm{RS}$ and $\mathrm{FBiH}$ ) and Brčko District. FBiH collected from direct taxes an amount equal to $3.0 \%$ of $\mathrm{FBiH}$ GDP; social contributions represented $16.2 \%$ of $\mathrm{FBiH}$ GDP and the revenue from indirect taxes (distributed by central government) reached $16.3 \%$ of $\mathrm{FBiH}$ GDP. As far as RS is concerned, the distribution was as follows (again in 2012): direct taxes: $4.87 \%$ of RS GDP; social contributions: $15.63 \%$ of RS GDP; and indirect taxes: $17.22 \%$ of RS GDP.

Trade union demands concerning the taxation system in $\mathrm{BiH}$

1. full implementation of the Law on taxation procedure, with a special emphasis on the control of the calculation of salaries and taxes, including the responsibility of the tax authorities to provide every beneficiary with an annual report on the social contributions that have been paid so that workers can have an insight into the liabilities paid into the funds by employers. The reason for this is that reality shows that workers, once the requirements for retirement, medical protection or unemployment benefit have been met, often find out that they cannot exercise any of their rights, even though the employer had deducted the contributions from gross salary

2. no taxation of the lowest salaries, with the minimum salary increased to at least $50 \%$ of the average salary in Republika Srpska and in the Federation of Bosnia and Herzegovina

3. introduction of progressive taxation rates on salaries, in such a way that salaries up to twice the average salary in $\mathrm{RS}$ and in $\mathrm{FBiH}$ should be subject to a tax of $8 \%$; 
salaries from two to five times the average salary should be taxed at $15 \%$; and all salaries exceeding five times the average salary (mainly managerial staff) should be taxed at $25 \%$. This would mean a fairer tax burden and fairer distribution

4. taxation of personal income should be defined in such a way that it does not affect too negatively the increase of salaries harmonised with the increase in productivity

5. analyse the effects of the exemption of employers from the payment of profit tax, where this is invested in the expansion of production and employment. These effects ought to be a number of new jobs and new workers compared with the savings due to unpaid taxes. Every employer who did not invest in production and in the creation of new jobs should pay the profit tax

6. to use legislation to prevent abuses by individual employers in terms of the appropriation of property and of filing for bankruptcy. Laws should ensure that the same owner cannot register a new legal identity until all the taxes and other liabilities of the existing company have been paid. Employers should secure their liabilities by use of their property (both personal and of family members), including the property of other companies

7. active measures should be taken in order to prevent unregistered work and to transform this into formal work arrangements, so that it could be registered within the taxation system and the workers insured and protected from the arbitrary behaviour of the employer

8. in terms of the more efficient work of inspectorates in RS, a new law on inspections should be adopted and, if necessary, other laws amended so as to create more efficient conditions for inspection, meaning that these are preventive for good employers and repressive for employers who refuse to apply the legislation in the field of the taxation system, labour laws and collective agreements

9. the introduction of differentiated VAT rates, meaning $0 \%$ or low rates for basic consumables, medication, education, etc; and higher rates for luxury products and services.

\section{Croatia $^{3}$}

Current situation

The basic task of the taxation system in the Republic of Croatia is to finance the central government (state) budget, the local administration and the extra-budgetary funds. The function of distribution is only a part of the primary task and is not an objective by itself.

In 2012, the general government disbursed around $43.3 \%$ of the gross domestic product of the Republic of Croatia, with state budget revenues of $€ 14.9 \mathrm{bn}(33 \%$ of GDP). Expenditure from the state budget amounted to $€ 16.4 \mathrm{bn}$.

3 The analysis in this sub-section was originally drafted by Boris Feis, MA in Economics and Executive Secretary in SSSH for economic and financial matters, in co-operation with Katarina Litva, from Croatian Independent Unions. 
The tax structure of the general government is as follows:

Table 1 - Tax structure (\% of GDP)

\begin{tabular}{|l|c|}
\hline Budget line & Expenditure as \% of GDP \\
\hline Direct taxes (capital, property, environment) & $2.5 \%$ \\
\hline Indirect taxes (VAT, excise duties, consumer tax) & $24.0 \%$ \\
\hline Labour taxes, including social contributions & $12.7 \%$ \\
\hline TOTAL & $39.2 \%$ \\
\hline
\end{tabular}

This clearly suggests that indirect taxes on consumers are overwhelming in Croatia, making up $61 \%$ of all taxes, followed by mandatory social contributions. Taxes on capital and property do not have any redistribution role and they do not significantly deter the arrival of foreign capital in Croatia.

\section{Income tax}

The income tax scale is progressive, and stands at $12 \%$ on incomes of up to 2200 kuna (€300); $25 \%$ on $2200-8800$ kuna; and $40 \%$ on incomes over 8800 kuna.

The maximum tax base for social contributions amounts to six times the average gross salary: 47646 kuna ( $€ 6$ 352). This means that the amount of mandatory contributions for a gross salary of 100000 kuna is the same, in absolute terms, as it is for 47646 kuna; in relative terms, the level of contributions for top salaries is lower than for medium ones.

Tax on capital

A profits tax is levied at a single rate of $20 \%$ applied to all companies making a profit, and in which the turnover from the sale of products and services exceeds 230000 kuna.

\section{Tax reforms}

Tax reforms in Croatia are taking place continually; as of 1997, the system has been harmonised with that of the EU. The tax system was assessed as being among the thirty leading systems in the world, but it is subject to constant changes in tax rates (particularly in VAT) and the inclusion of new forms of collection (the latest example being the so-called fiscalisation of sales in open green markets). Previously, control of the collection of taxes and contributions used to be arbitrary and inconsistent, and inappropriate to the functioning of a market economy. However, no tax reform has been attempted which introduces an effective and fair system of the taxation of property; this is due to the opposition of various political and interested parties (in particular, new rich groups after 1990). 
Trade union views and demands concerning the Croatian tax system

1. the taxation system is ineffective, as the shadow economy evades tax payments. This encompasses at least $15 \%$ of the economy of Croatia (and some authors claim even $30 \%$ )

2. tax supervision is partial and often depends on politics, and it is a source of corruption. The tax administration should be reformed in terms of its efficiency, including the affirmation of its position in society

3. the main tax burden is borne by the poorest groups of the population through the consumer tax, whereas the property tax favours the rich and does not constitute a significant source of state financing. Trade unions are striving for an income tax policy which is more fair, and that another rate should be introduced: with $50 \%$ being levied on incomes exceeding 15000 kuna, which would facilitate the better taxation of incomes which are several times larger than the average

4. the trade unions are in favour of a property tax, particularly among those groups which have become rich thanks to privatisation. However, the trade unions also warn that the specifics of Croatia have to be acknowledged should a property tax be introduced, since about $85 \%$ of the population has property which serves only to satisfy basic residential needs and, as such, it should not be taxed

5. the majority of para-fiscal burdens should be terminated unless they can be made better to serve the preservation of natural resources (e.g. forests).

6. the rationale for the existence of the second pillar of the pensions system should be defined

7. a stronger supervision of the banking system should be introduced, as well as the taxation of the surplus profits of the banks

8. the taxation system should be easily understandable, simple and stable. However, the trade unions oppose the introduction of a single flat tax rate, on the grounds that there is no evidence that it helps the economy (it did not contribute to the development of the economy in Serbia, Russia, Bulgaria or elsewhere).

Kosovo 4

Current situation

Total budget revenues have increased, amounting to $€ 1482 \mathrm{bn}$ in 2012 . Revenues as a share of GDP remained almost constant during 2010 and 2011, but there was a significant increase in 2012 mainly as a result of domestic and foreign borrowing. Total expenditure has increased continuously. Wages and salaries as a category of economic costs have risen from $26 \%$ in 2010 to $28 \%$ in 2012, while other categories have marked a decline. The increase in expenditure on wages and salaries is due to a raise in the salaries of civil servants and to a transfer of new responsibilities. Central government expenditure in 2012 was $€ 1060 \mathrm{bn}$.

4 Ali Vitija,for BSPK Kosova, contributed to the analysis of this sub-section. 
Types of taxes

Kosovo has laid out a taxation system that is simple, transparent and with low taxes for individuals and businesses. Furthermore, the government is introducing a system of tax incentives to support domestic production.

Dependent on their annual income, domestic legal entities and the permanent establishments of foreign legal entities are taxed in line with a progressive scale as follows: up to $€ 5000-€ 37.50$ /quarter; $€ 5001-€ 50000-3-10 \%$ of income; $€ 50000$ and over $-10 \%$ of income. Corporate income tax is paid quarterly in advance, based on quarterly net income predictions.

Personal income tax applies to those receiving income from Kosovo sources and also to foreign incomes received by Kosovo residents. The rate of personal income tax depends on annual income on a progressive scale and ranges from $0 \%$ to $10 \%$ :

Table 2 - Personal income tax rates in Kosovo

\begin{tabular}{|l|c|}
\hline Monthly income (€) & Rate \\
\hline 80 & $0 \%$ \\
\hline $81-250$ & $4 \%$ \\
\hline $251-450$ & $8 \%$ \\
\hline Over 450 & $10 \%$ \\
\hline & \\
\hline Annual income $(\boldsymbol{\epsilon})$ & $0 \%$ \\
\hline $0-960$ & $4 \%$ of the amount over $€ 960$ \\
\hline $960-3000$ & $€ 811.60+8 \%$ of the amount over $€ 3000$ \\
\hline $3001-5400$ & $+10 \%$ of the amount over $€ 5400$ \\
\hline 5401 and over & \\
\hline
\end{tabular}

Property tax was introduced in 2002 and is collected at local government level by the municipal councils, which define the rates on an annual basis. The rates range between $0.05-1 \%$ of the market value of the property for residential property; commercial property; industrial property; agricultural property; immovable abandoned property and uninhabited buildings. Rent tax stands at $9 \%$.

Trade union demands concerning the taxation system and budgetary policy in Kosovo (BSPK)

BSPK proposes a number of issues under this heading:

1. new sources of budgetary funds should actively be used, including funds collected from privatisation; funds from the Pension Trust Fund of Kosovo; the investment of remittances not only their use for consumption; and funds from external donors as well as EU funds 
2. a review of budget allocation by sector. In the context of the need for an increase in the budget, sectors which deserve a higher share of the budget are economic development (via investments in production, agriculture, industry and energy); education and science (the relevance of educational curricula to labour market needs and training in new technologies); and health and welfare (the introduction of health insurance, a law on pensions, the establishment of a social fund, upgrading social policy schemes, etc.). Capital investments requiring larger budgetary funds (highways and regional roads) should be initiated through concessions, EU funds and flexible loans from the IMF and the World Bank

3. in terms of macroeconomic policies, the union seeks tax policy reforms with the objective of creating more favourable conditions for local producers and foreign investments, and reducing the informal sector (accompanied in the latter case by a strict implementation of the law); raising taxes and fees for insurance companies and banks offering micro-finance banks; and reducing interest rates with the aim of facilitating a more favourable business credit environment

4. there has already been a change in the tax system with corporation tax bands reduced from $20 \%$ to $10 \%$ while the personal income tax rates were changed from $5 \%, 10 \%$ and $20 \%$ to $4 \%, 8 \%$ and $10 \%$ (zero being constant). At the same time the standard VAT rate was increased from $15 \%$ to $16 \%$ and excise duty was increased for certain products. These reforms, however, have had no positive impact on economic development, employment growth or the reduction of poverty, and should be changed

5. BSPK would like to see a greater differentiation in labour taxes according to experience and qualifications; lower taxes for people with children; and higher taxes for higher wages. Additionally, there needs to be introduced a unique tax system across the entire country; tax registration for all businesses; and the combat of tax evasion by a joint tax force

6. the existing funded pension scheme should be replaced by a Bismarck system

7. the main challenges in the field of employment, social affairs and poverty include the following issues:

- the improvement of statistics on employment and the introduction of an electronic system for their management

- the creation of an accurate database for social schemes and permanent monitoring and control of social transfers in order to avoid social fraud

- strengthening the labour inspectorate by increasing the number of personnel and raising their professional development

- monitoring the implementation of laws and the acceleration of the procedures of the Economic Court in cases of the violation of labour law

- the creation of new jobs by improving the tax climate for business. A suitable fiscal package and combating corruption and the informal sector, as well as the facilitation of procedures and the reduction of administrative barriers are some of the conditions that must be implemented for investment, growth and job creation 
- $\quad$ increasing the budget for active measures in the labour market remains one of the other challenges in respect of labour and employment. So far, the majority of such measures is being funded by foreign donor organisations

8. finally, Kosovo's system of social protection is currently under-developed: there is still a need to regulate and organise unemployment insurance, child allowances, health insurance and many other social services which, in EU countries, are provided by public institutions.

\section{Republic of Macedonia ${ }^{5}$}

Current situation

In 2012, total budget revenue covering all levels of government amounted to $€ 2245 \mathrm{bn}$, representing $29.0 \%$ of GDP, while total government budget expenditure amounted to $€ 2534 \mathrm{bn}$, or $32.7 \%$ of GDP. Thus, the general government deficit was $€ 289 \mathrm{~m}(3.7 \%$ of GDP).

Total tax revenues (including social contributions) totalled $€ 1909 \mathrm{bn}(24.6 \%$ of GDP). This included the following elements:

- personal income tax $(€ 155.33 \mathrm{~m}$, representing $8.14 \%$ of total tax revenues and $2.01 \%$ of GDP)

- profits tax, arising mainly from the tax collected on the level of monthly advances and on the basis of chargeable tax on paid dividends and other distributed profits. This amounted to $€ 59.4 \mathrm{~m}$ ( $3.11 \%$ of total tax revenues and $0.77 \%$ of GDP)

- other income tax revenues amounted to $€ 53.3 \mathrm{~m}(2.79 \%$ of total tax revenues and $0.69 \%$ of GDP

- revenue from taxes on personal accounts were $€ 16.23 \mathrm{~m}(0.85 \%$ of total tax revenues and $0.21 \%$ of GDP.

Social contributions reached $€ 662.8 \mathrm{~m}$ (34.73\% of total tax revenues and $8.6 \%$ of GDP. Such contributions are exclusively paid by employees and amount, in total, to $27 \%$ of gross salary: pensions and disability insurance accounts for $18.0 \%$; primary health care for $7.3 \%$; the employment fund for $1.2 \%$; and additional health care for $0.5 \%$. Taxation of labour is via a flat tax system with the personal income tax rate standing at $10 \%$ (and raising $2.01 \%$ of GDP). The total labour wedge is, therefore, $37 \%$.

The lowest base for the calculation of social contributions for 2013 is $€ 249(50 \%$ of the average paid salary of $€ 498$ published in January 2012; while the highest base amounted to $€ 2988$ (i.e. six times the average paid salary).

The corporate income tax rate is also $10 \%$. Pursuant to the Law on Corporate Income Tax, companies that have realised total annual revenues from any source of between $€ 48781$ and $€ 97561$ may calculate and pay an annual 1\% tax on their total income in the context of a 'simplified tax regime for companies', instead of paying corporate income tax. The taxation regime that companies select can not be changed for three years, including the current tax year. Companies whose total revenue for the year does not exceed $€ 48780$ are exempt from paying annual corporate income tax.

5 This sub-section was developed by Ljubica Dekovska. 
Property tax is proportional and ranges from $0.10 \%$ to $0.20 \%$ at the discretion of the council of the relevant municipality or city, while a property sales tax ranges from $2 \%$ to $4 \%$, again at the discretion of the municipal or city council.

\section{Tax and budgetary reforms}

Given that, for success in business the two most important things are low taxes and a predictable tax policy, but also since Macedonia is a relatively poor country that lacks domestic capital, the government has decided to implement tax reform to stimulate business development, reduce the grey economy and corruption, and convince businesses to invest their money by establishing or expanding their businesses and, at the same time, attract foreign capital.

The major reforms to the tax system have been introduced either side of the crisis. The flat rate tax reduced the previous rates of personal income tax from $15 \%, 18 \%$ and $24 \%$ to $10 \%$ in 2008; while corporate income tax, introduced in 2007 at $15 \%$, was lowered to $10 \%$ in 2008 . The government has introduced four packages of anti-crisis measures, and in 2009 reformed the system of the payment of salaries, switching to a gross system with the worker becoming responsible for the payment of income tax and social insurance contributions. It has also decreased the rate of social security contributions, from the $32.5 \%$ which applied in 2008 to the $27 \%$ which applies now.

The changes in the tax system and the introduction of an integrated collection of social contributions and personal income tax, as well as an increase in the effectiveness of the Public Revenue Office, has led to a more efficient tax administration and a broadening of the tax base.

Trade union demands concerning the taxation system and budgetary policy in Macedonia

The Macedonian trade unions are seeking the following further reforms:

1. greater transparency in the spending of budget funds; the participation of trade unions in the drafting of the budget and a more appropriate allocation of budget funds

2. more budget funds released for capital investment that will directly affect the improvement of the investment climate and have an impact on economic growth, reduce unemployment and increase the employment rate in the country

3. a small, effective and efficient public administration which will not burden the budget

4. the government had, by March 2013, settled its liabilities to companies and adopted the Law on Financial Discipline but, due to a lack of adequate information, trade unions believe it should continue to fulfil its liabilities towards companies (based on VAT returns or a commitment to a particular service for governmental purpose) in a timely way

5. respect for and consistent application of the Law on the Minimum Wage, increased inspection activities regarding its implementation and responsibility for its application to be passed to the Public Revenue Office. 


\section{Montenegro 6}

\section{Current situation}

Public revenues for 2013 were $€ 1420.6 \mathrm{bn}$, or $42.9 \%$ of GDP (€3 $311 \mathrm{bn}$ ). Compared to 2012 , they are higher by $9.3 \%$, which represents nominal growth of $€ 120.7 \mathrm{~m}$. The growth in revenues is the result of the enforcement of measures aimed at the suppression of the grey economy and the economic recovery taking place since the beginning of the year, including the introduction of higher tax rates.

Public expenditure for 2013 was $€ 1508.5 \mathrm{bn}$, which is $45.6 \%$ of GDP and higher by $1.0 \%$ compared to the same period in 2012 . It is the austerity measures which have been pursued by the government in 2013 which facilitated this result.

In early 2013, a set of crisis measures related to fiscal adjustment was introduced with the sole purpose of stopping the deterioration in the fiscal parameters, primarily the decline in the collection of revenues and the subsequent growth in the deficit and in the level of public debt. This set of fiscal measures meant the introduction of a 'crisis' tax of $15 \%$ on incomes exceeding the national average and an increase in VAT (from $17 \%$ to $19 \%$ ), although this partly reflects the EU harmonisation process.

Throughout the year, measures were also pursued aimed at the reduction of the grey economy, which affected the spreading of the tax base and the improvement of fiscal discipline. Thanks to the successful enforcement of these measures, 2013 saw an increase in the revenue collection rate, compared both to the budgeted figure and the 2012 out-turn, which has had positive effects on fiscal consolidation and the stabilisation of public finances.

\section{Tax rates}

Personal income tax is divided into two levels: for gross monthly incomes of up to $€ 720$, the tax rate is $9 \%$; for amounts above this figure it is $15 \%$. Social contributions paid by employees are $33 \%$ for gross incomes up to $€ 720$; and $39 \%$ for incomes above this amount). Payroll tax, paid by the employer, is $15 \%$ while the employer's social contributions are $25 \%$.

The profits tax rate is single, amounting to $9 \%$ (corporate profit tax, tax on SMEs and company income tax).

The property tax rate is determined by local self-governments, which prescribe the legal minima within the framework of a national legal maximum of $1 \%$. The tax rate on the sale of property is proportional and amounts to $3 \%$ of the tax base; if a newlybuilt residential or business building is purchased directly from the investor, only VAT is paid $(19 \%)$.

6 Lela Perovic and Tatjana Vukosavović contributed to the development of this sub-section. 
Trade union demands concerning the taxation system and budgetary policy in Montenegro

Trade unions believe that the shortcomings of the existing system can be summarised as follows:

- the amount of capital investment is insufficient and represents a bad indicator for foreign investors

- the infrastructure is insufficiently developed

- there is an imbalance between the rates of direct and indirect taxes

- the role of local self-government in the system of taxation is unsatisfactory (the system should be centralised or an adequate system of control introduced)

- there is no single database and automatic exchange of information (for all users)

- control mechanisms related to the collection of tax payment should be improved.

Considering the economic crisis, the crucial solutions are based on fiscal and financial discipline. It is beyond comprehension that tax evasion, including the payment of duties to the state, is tolerated. Taxes are collected from ordinary citizens, while those who are well-resourced deliberately carry out tax evasion to the detriment of all citizens and the state itself. The trade unions require the government to collect tax from all those who have several apartments, villas, weekend houses and luxurious vehicles. There are around 120000 vacated and temporarily vacated apartments in Montenegro, which are mainly rented, while the state loses annually on tax to the tune of around $€ 32 \mathrm{~m}$.

The trade unions also insist on enhancing the control function of the state in terms of the enforcement of laws related to tax policies, and severe sanctions as regards those who do not respect these legal provisions.

Unions advocate the development of tourism (Montenegro has around $1.5 \mathrm{~m}$ tourists during the summer season), and many houses and apartments are rented during the summer season. These are owned by Montenegrin nationals as well as foreign citizens, but the state has no records of them, let alone draw any financial benefit, as a result of accommodation being unregistered. Around $60 \%$ of accommodation capacity is illegal and that represents a substantial monetary resource. Tourism experts believe that this represents an annual financial loss of c. $€ 500 \mathrm{~m}$. The grey economy creates unfair competition and investors avoid such destinations.

Unions propose the introduction of strict inspection controls aimed at the identification of illegal visitors and the proper collection of taxes and resident fees, and severe penal policies for all those who violate the legal provisions.

Furthermore, the introduction of a progressive taxation system would be important, because:

- progressive taxation ensures bigger funds for the state budget, which is able to facilitate an adequate distribution policy. It is possible in this way to introduce different taxation benefits and exemptions, aimed at acquiring more fairness in taxation and, at the same time, a reduction in the differences in incomes acquired by different individuals. However, this is not only dependent on tax rates and the span of the tax base, but also on the attitude of taxpayers 
- progressive taxes facilitate a better implementation of an active taxation policy. Active taxation includes the use of tax instruments aimed at both micro- and macroeconomic impacts: in the former case, the state may influence the current allocations of economic resources; and, in the latter, the state has an influence, through progressive taxation, on employment, prices, exports and imports

- progressive taxation has a strong stabilising effect on the economy, as progressive taxes have an anti-cyclical effect as regards economic trends. They alleviate cyclical oscillations and act to increase or decrease aggregate demand. Progressive tax is used as an automatic stabiliser

- progressive taxation may be used to compensate for the effects of regressive taxes, primarily indirect ones (excise duties, VAT). In this way, the tax system acquires a proportionate character. The effect of progressive income taxation is, otherwise, neutralised by indirect taxes on consumption, which are regressive.

\section{Republic of Serbia}

Current situation

The basic fiscal aggregates are public revenues and public expenditures. In 2012, public revenues took up $43.7 \%$ of the gross domestic product of the Republic of Serbia; while public expenditures took up $49.8 \%$. This means that the deficit of the state sector (the consolidated state) amounted to $6.1 \%$ of GDP.

For 2013 and the coming years, an increase in the share of public revenues and a reduction in that of public expenditures have been planned, which also implies a reduction in the share of the deficit in the state sector. Considering the fiscal changes in the first half of the present year, however, the planned events will, most probably, not take place.

Tax can only be introduced with legislation, and these include taxes on consumption, personal incomes, profits, property and the transfer of property. The law also introduces contributions to mandatory social insurance for pensions and disability insurance; health care insurance; and unemployment insurance.

Table 3 shows the basic structure of planned revenues and income, and expenditures and costs in the budget of the Republic of Serbia budget for 2013.

7 Rajko Kosanović contributed the analysis in this sub-section. 
Table 3 - Basic structure of revenues and income in the Republic of Serbia budget for 2013

\begin{tabular}{|l|c|}
\hline DESCRIPTION & $\mathbf{\%}$ \\
\hline Total revenue and income & 100.00 \\
\hline Tax revenues & 87.18 \\
\hline Personal income tax & 5.57 \\
\hline Corporate profit tax & 5.51 \\
\hline VAT & 46.29 \\
\hline Excise duties & 24.88 \\
\hline Customs duties & 3.96 \\
\hline Other tax revenues & 0.98 \\
\hline Non-tax revenues & 12.66 \\
\hline Donations & 0.16 \\
\hline
\end{tabular}

Income tax rates in the Republic of Serbia stands at 10\%, as does the tax on revenues from entrepreneurial activities. The corporate profits tax is higher, at $15 \%$, while the tax on copyright revenues reaches $20 \%$.

For financing benefits in the field of pensions and disability insurance, health care insurance and unemployment insurance, organisations for mandatory social insurance are entitled, in line with the law, to access public revenues and income in the form of contributions for mandatory social insurance; donations and transfers; and other revenues and income.

The rates of taxes and contributions on the salaries of employees in the Republic of Serbia are as follows:

1. paid by employees:

- income tax $10.00 \%$

- contribution for pensions and disability insurance $13.00 \%$

- contribution for health care insurance

$6.15 \%$

- contribution for unemployment insurance 
2. paid by employer:
- contribution for pensions and disability insurance
$11.00 \%$
- contribution for health care insurance
$6.15 \%$
- contribution for unemployment insurance
$0.75 \%$

Trade union demands concerning the taxation system in Serbia

CATUS and UGS Nezavisnost, being the only two representative trade union centres in Serbia, see the following basic problems related to taxation policies in the Republic of Serbia:

- an express lack of financial discipline in terms of the obligation to pay taxes and contributions for mandatory social insurance

- a failure to apply appropriate methods to control respect for the obligation to pay taxes and contributions

- the lack of appropriate sanctions as regards negligent tax and contribution payers

- a highly entrenched informal economy (due to relatively high fiscal burdens on labour; a non-transparent tax system; inadequately-organised tax administration; a high level of tolerance of the grey economy; economic crisis; the high unemployment rate; weaknesses in the process of privatisation; a high level of illiquidity; a significant share of cash transactions in total payments; etc.)

- a high level of corruption.

In indicating the basic problems related to taxation policies, the trade unions have suggested ways in which these problems could be resolved which, among other things, include: combating the informal economy, combating corruption and establishing a more efficient operation of the tax authorities.

In the trade union view, it is necessary to:

- organise the tax administration better

- apply appropriate methods of control concerning the obligation to pay taxes and contributions

- apply proportionate sanctions on negligent tax and contribution payers

- reduce the proportion of cash transactions in total transactions

- enforce preventive, stimulatory and penal measures aimed at the reduction in the informal economy

- pursue a national strategy to combat corruption.

Comparison between the countries of the western Balkans and of the EU

General government revenue and expenditure

A comparison between the macro-economic figures of the countries of the western Balkans and those of the EU countries has to be handled with some reservations given the importance of the informal economy in the western Balkans. 
Table 4 - General government total revenue and expenditure (\% of GDP)

\begin{tabular}{|l|c|c|}
\hline & Revenue & Expenditure \\
\hline Serbia (2012) & 43.7 & 49.8 \\
\hline Montenegro (2013) & 42.9 & 45.6 \\
\hline Macedonia (2012) & 29.0 & 32.7 \\
\hline Federation of Bosnia i Herzegovina (2012) & 40.3 & 40.1 \\
\hline Republika Srpska (2012) & 42.6 & 41.2 \\
\hline Kosovo (2012) & 26.8 & 29.0 \\
\hline Croatia (2012) & 39.2 & 43.3 \\
\hline EU 28 on average (2012) & 45.4 & 49.4 \\
\hline
\end{tabular}

Serbia has a high public revenue and expenditure ratio in terms of GDP, and is very close to the EU average on both. All other western Balkan countries have lower values.

Table 5 - Structure of general government total revenue (\% of GDP)

\begin{tabular}{|l|c|c|c|c|}
\hline & $\begin{array}{c}\text { Direct } \\
\text { taxes }\end{array}$ & $\begin{array}{c}\text { Indirect } \\
\text { taxes }\end{array}$ & $\begin{array}{c}\text { Social } \\
\text { contrib- } \\
\text { utions }\end{array}$ & $\begin{array}{c}\text { Other } \\
\text { revenue }\end{array}$ \\
\hline Serbia & 6.8 & 19.8 & 11.6 & 5.5 \\
\hline Montenegro & 7.6 & 18.5 & 12.4 & 4.8 \\
\hline Macedonia & 3.7 & 12.4 & 8.6 & 4.2 \\
\hline Federation of Bosnia i Herzegovina & 3.0 & 16.3 & 16.2 & 4.7 \\
\hline Republika Srpska & 4.9 & 17.2 & 15.6 & 4.8 \\
\hline Kosovo & 3.1 & 19.2 & 0 & 4.4 \\
\hline Croatia & 2.5 & 24.0 & 12.7 & 0 \\
\hline EU-28 on average (2012) & 12.9 & 13.6 & 14.0 & 4.9 \\
\hline
\end{tabular}

In all western Balkan countries, the government's revenue from direct taxes (as a percentage of GDP) is low, but it is particularly low in Croatia, $\mathrm{FBiH}$, Macedonia and Kosovo; meanwhile, income from indirect taxes is generally high across the western Balkans, but particularly so in Croatia, Serbia and Kosovo.

Social contributions are particularly high in $\mathrm{BiH}$, in terms both of $\mathrm{FBiH}$ and $\mathrm{RS}$; in Kosovo, social contributions play no role in the general government budget. 
Table 6 - Share of direct and indirect taxes and of social contributions in general government total revenue

\begin{tabular}{|l|c|c|c|}
\hline & Direct taxes & $\begin{array}{c}\text { Indirect } \\
\text { taxes }\end{array}$ & $\begin{array}{c}\text { Social } \\
\text { contributions }\end{array}$ \\
\hline Serbia & 15.6 & 45.3 & 26.5 \\
\hline Montenegro & 17.7 & 43.1 & 28.9 \\
\hline Macedonia & 12.7 & 42.8 & 29.5 \\
\hline Federation of Bosnia i Herzegovina & 7.2 & 40.3 & 40.2 \\
\hline Republika Srpska & 11.3 & 40.5 & 36.8 \\
\hline Kosovo & 11.6 & 71.6 & 0 \\
\hline Croatia & 6.4 & 61.2 & 32.4 \\
\hline EU 28 on average (2012) & 28.4 & 30.0 & 30.8 \\
\hline
\end{tabular}

All the countries of the western Balkans rely mainly on indirect taxes to fund their public budgets. This is particularly true for Kosovo and for Croatia. This latter country has a very low share of direct tax income: this is a quite remarkable phenomenon since Croatia has the highest personal income tax rates in the region. The explanation for this can be found in the way that the tax rules are implemented in Croatia, and the presence of numerous exemptions, as well as tax allowances and credits.

Types of taxes and tax rates

Table 7 - Personal income tax (statutory rates)

\begin{tabular}{|l|c|c|}
\hline & Rates (\%) & Basic tax allowance \\
\hline Serbia & 10 & $\mathrm{n} / \mathrm{s}$ \\
\hline Montenegro & $9-15$ & $\mathrm{n} / \mathrm{s}$ \\
\hline Macedonia & 10 & $€ 118.20 /$ month \\
\hline Federation of Bosnia i Herzegovina & 10 & $€ 1837 /$ year \\
\hline Republika Srpska & 10 & $\mathrm{n} / \mathrm{s}$ \\
\hline Kosovo & $4-8-10$ & $€ 960 /$ year \\
\hline Croatia & $12-25-40$ & \\
\hline Top rate EU-28 on average (2014) & 39.4 & \\
\hline Top rate Sweden (2014) & 56.9 & \\
\hline Top rate Norway (2014) & 39.0 & \\
\hline
\end{tabular}


Personal income tax rates tend to be on a flat rate basis and low in all the western Balkan countries, with the exception of Croatia and Montenegro where a progressive income tax rate applies. We have seen above that progressive income tax rates alone are not a guarantee of a reasonable income from direct taxes: other elements also play a role.

Table 8 - Corporate tax rates (statutory rates) (\%)

\begin{tabular}{|l|c|c|}
\hline & $\begin{array}{c}\text { Rates (legal } \\
\text { entities) }\end{array}$ & $\begin{array}{c}\text { Rates } \\
\text { (entrepreneurs, } \\
\text { physical entities) }\end{array}$ \\
\hline Serbia & 15 & 10 \\
\hline Montenegro & 9 & n.s. \\
\hline Macedonia & $0-1-10$ & $0-1-10$ \\
\hline Federation of Bosnia i Herzegovina & 10 & 10 \\
\hline Republika Srpska & 10 & 10 \\
\hline Kosovo & $3-10$ & n.s. \\
\hline Croatia & 20 & 20 \\
\hline Adjusted top rate EU-28 on average (2014) & 23.1 & \\
\hline Highest rate in EU: France (adjusted top rate) & 38.0 & \\
\hline Norway (adjusted top rate) & 20.0 & \\
\hline
\end{tabular}

With the exception of Croatia and Serbia, corporate tax rates are very low in western Balkan countries.

Table 9 - Social contributions ( $\%$ of gross wage)

\begin{tabular}{|l|c|c|}
\hline & Paid by employer & Paid by employee \\
\hline Serbia & 17.9 & 19.9 \\
\hline Montenegro & $9.8(+15 \%$ payroll tax $)$ & $33-39$ \\
\hline Macedonia (with min. and max. ceiling) & 0 & 27.0 \\
\hline Federation of Bosnia i Herzegovina & 10.5 & 31.0 \\
\hline Republika Srpska & 0 & 33.0 \\
\hline Kosovo & 5.0 & 5.0 \\
\hline Croatia & 15.5 & 20.0 \\
\hline & & 18.0 \\
\hline Austria (with max ceiling) & 21.5 & 13.0 \\
\hline Belgium (no ceiling) & 34.6 & \\
\hline
\end{tabular}


Social contributions are very high in Montenegro, FBiH and Serbia. They are extremely low in Kosovo (where they are focused on a funded private pension scheme). It is also remarkable that, in all western Balkan countries (with the exception of Kosovo), employees pay the bulk of social contributions; in Macedonia and $\mathrm{FBiH} / \mathrm{RS}$, they even pay all of them.

Table 10 - Tax wedge for worker on average salary (\% of total labour cost)

\begin{tabular}{|l|l|}
\hline Serbia & 39.9 \\
\hline Montenegro & 56.0 \\
\hline Macedonia & 37.0 \\
\hline Federation of Bosnia i Herzegovina & 41.2 \\
\hline Republika Srpska & 39.7 \\
\hline Kosovo & 17.0 \\
\hline Croatia & 39.6 \\
\hline EU-27 on average for single worker on 67\% of average salary (2013) & 36.8 \\
\hline Belgium for single worker on 67\% of average salary (2013) & 50.1 \\
\hline Norway for single worker on 67\% of average salary (2013) & 34.1 \\
\hline
\end{tabular}

The tax wedge for workers is relatively high (mostly around 40\%). One country has an above-average figure: Montenegro; while one other has a very low wedge: Kosovo.

Tax and budgetary reforms in the countries of the western Balkans

All the countries of the western Balkans have faced the economic and social consequences of the economic and financial crisis, just as all European countries have done.

However, and in contrast to most other European countries, western Balkans countries were then (and as they continue to be) confronted with large informal sectors (and corruption) as well as low levels of formal employment. All together, this is very detrimental to state budgets and limits the possibilities of the government to engage in active investment and social policies.

That is why governments have focused on the consolidation of their budgets and, at the same time, on measures to attract new investment, and foreign direct investment in particular. Several measures in this direction have already been implemented, while others are planned. It is important that we examine the effectiveness of each of these measures, and we turn to this in the final section of this article. 
Reform proposals formulated by the trade unions of the countries of the western Balkans

Based on the data displayed in the previous sections, one can conclude that, from a trade union point of view, the tax systems in the countries of the western Balkans are unfair, not only in their structural design but also in their operation.

They are unfair in their structure partly because of the over-heavy contribution of indirect taxes but also because of the too-limited taxation of higher incomes (both personal and corporate) as well as of large property (income). They are also unfair in their operation due to a lack of efficiency, effectiveness and compliance.

During the last few years, there has been a clear trend in western Balkans countries towards higher indirect taxes, low flat rate taxes on personal income and low taxation rates for corporate income, together with lower social contributions (for employers).

Raising the cost/benefit question about this move, the evidence so far - in western Balkans countries and elsewhere - suggests that the expected direct effect of the introduction of low flat rate taxes, namely an increase in FDI (and thus also in formal employment and budget revenue), alongside a decrease in the shadow economy, has not materialised. On the contrary, such a move has led to a legitimisation and a stabilisation of the informalities in the economy instead of their curbing or elimination. It has also sharpened the shortage of public revenues and has made governments more dependent on foreign credits, often provided by the international financial institutions.

Over 2010-2012, the net inflow of foreign direct investment in the group of six western Balkans countries decreased by $20 \%$ (from $\$ 4113 \mathrm{bn}$ to $\$ 3294 \mathrm{bn}$ ). Remarkably, the only country in this group which could welcome a strong increase in FDI was Croatia: precisely, the country with a progressive personal income tax system and the highest corporate tax rate in the region. In 2012, 42\% of the net inflow of FDI ( $\$ 1395 \mathrm{bn})$ went to this country.

In order to make the tax systems more fair, efficient and effective, the trade unions of the countries of the western Balkans have proposed several measures, taking into account the specific situations in the different countries. The trade unions have also made some proposals concerning state budgets. These measures are grouped together into clusters below. The list is neither exhaustive nor necessarily applicable integrally to each country: the hard core measures would, however, merit a general application.

These measures are structured around the following headings:

\section{Budget policies}

- in several countries, there is an urgent need for budget increases and for a higher share in the budget for education, capital investment projects (mainly in public infrastructure), social welfare and active labour market policies (in particular, training)

- non-productive expenditure should be reduced

- there is a need for the better management of public finances, more adequate budget planning, more efficient allocation of budget spending and more budgetary discipline by governments. An independent public body should monitor public finances

- trade unions should be involved in the drafting of the state budget 
- a 'lighter', but more efficient, public administration is recommended

- governments should depend less on loans from international institutions by generating more of their own tax income.

\section{Tax administration}

Here, there is a need for:

- re-organisation of the tax administration and of tax procedures in terms of creating more efficiency, more effectiveness and a more correct functioning of tax supervision and tax collection and control

- investment in capacity building within the tax administration and of tax inspectors: sufficient staffing; permanent training and upgrading of skills; investment in IT equipment; and the creation of databases. A decent salary for tax inspectors is also necessary in order to avoid corruption

- accountability of the tax administration vis-à-vis taxpayers, the transparency of the tax procedures and the possibilities of appeal for taxpayers.

\section{Tax structure, types of taxes and tax rates}

The following measures are necessary:

- introduction of a (more) progressive system of personal income taxation, with a higher top rate and tax exemption for those on the lowest salaries (up to $50 \%$ of average earnings) in order to rebalance the system between direct and indirect taxes and to bring more fairness into the system, to allow a greater re-distribution of income and more active policies

- greater differentiation of VAT rates: zero rate, or lower rate, for basic goods and services and higher rates for luxury products/services (e.g. weekend houses, large villas, luxury cars, boats, etc.)

- in order to broaden the tax base, there needs to be a critical examination of the numerous tax deductions, tax exemptions, tax allowances and tax credits, both for personal income tax and for corporate tax. Are they really all justified and effective?

- companies who do not deliver the promised recruitment of new staff in exchange for any kind of tax concessions (be it subsidies or exemptions) should reimburse the concession, that means a restitution of the subsidy or the payment of the full rate of corporate tax

- the majority of small para-fiscal burdens (i.e. fees) should be abolished

- property taxes should contribute more to state revenues. Large and multiple properties should be properly taxed; basic property used for residential purposes should be tax exempt or taxed at a low rate

- the potential of higher taxes on capital income (from leasing, property trading, interests, dividends, etc.) should be explored

- environmental taxes should be developed as part of an integrated and coherent waste management system (higher taxes for landfill, separate collection of waste at municipal level, recycling contribution, investment in recycling industries, etc.). Environmental taxation delivers a double dividend

- higher tax on insurance and bank transactions 
- a greater centralisation of the tax system would allow the more equal treatment of all taxpayers and more efficient tax control and collection.

\section{Tax and social fraud, tax evasion and corruption}

The fight against corruption, tax fraud and tax evasion can only be won by governments if they succeed in restoring confidence in government and in guaranteeing respect for the rule of law.

It is of utmost importance to reduce, by all means - prevention, sensitivisation and repression - the level of tolerance for the grey economy, for the evasion of social contributions, for tax fraud and for corruption.

Stricter and more regular control is needed on tax declarations concerning private earnings and of business profits in order to reduce the substantial under-reporting of earnings and profits and increase financial discipline.

Strict control is also required as regards the application of laws on minimum wages and on the correct amount of payments and transfers to the Public Revenue Office (PRO) in respect of social contributions; the PRO should, each year, send workers a report on the social contributions that have been received (and the taxes paid, if any).

State bonds should no longer be emitted on paper but in a digital form.

Unions also believe that stronger supervision of the banking and insurance sector is also needed.

Better prevention mechanisms ought to be introduced as regards public procurement policies; the main contractor should be liable for sub-contractors.

Cash transactions should be limited: all important payments should proceed via bank accounts (or credit cards) so that they become traceable.

Different databases should be developed for tax, social, financial and employment services and used in a co-ordinated way (i.e. they must be interlinked).

The unjustified and undeclared wealth of private individuals (senior public and other officials, politicians, business leaders, civil servants, etc.) should be examined at source and proportionate sanctions taken in cases of the violation of the law.

The functioning of the different inspection services (social protection, employment, direct and indirect taxation) should be co-ordinated and operations in the field should be carried out jointly (via a joint taskforce).

For sensitive sectors of the economy (construction, trade, transport and hospitality, restaurants and catering), a labour card and badge can be useful as a registration and control instrument.

In tourist areas, rented apartments/houses and tourists should be registered on a central register and effectively taxed (tax on the rental income and a tourist tax).

Bilateral, or multilateral, automatic exchange of information agreements in the field of direct and indirect taxation can be very useful.

Unions also believe that there is a need also to regulate and control transfer pricing.

On the yearly tax declaration form, a question can be raised as to whether the taxpayer has a bank account or insurance contract abroad. 
For black or grey capital repatriated from abroad, a regularisation and amnesty procedure can be foreseen, associated with reasonable financial penalties.

All financial transactions with tax havens - be they direct or indirect - should be checked as regards their economic justification and interest; meanwhile, dividend and royalty payments made to these countries should be taxed at a higher rate.

\section{Social protection / social assistance}

Countries need to spend more money from the unemployment fund on active labour market policies (e.g. the financing of training) instead of on passive unemployment benefits.

In order to avoid the assistance/benefits trap, the thresholds for allowing a combination of social assistance/social benefits support and low-paid work in the formal sector should be revised. If people lose support once they take up a small formal job, they will be tempted not to take up that job or to work in the grey economy.

The rationale for second pillar pensions should be defined. In Kosovo, there exists only a mandatory funded pension scheme, whereas the trade unions have been asking for the replacement of that scheme with a pay-as-you-go (Bismarck type) one.

\section{Attracting new investment (FDI)}

The trade unions universally underline the importance of the tax and fiscal system for investment decisions and industrial location.

However, at the same time, they stress that, besides the taxes, other elements are equally important for future investors, such as:

- the availability of good public infrastructure

- the rationalisation of procedures for starting up a new business or for the expansion of existing investment: procedures should be transparent, less lengthy, less burdensome (or less bureaucratic) and less expensive (with fewer registration costs)

- a stable and secure business environment; clearly-allocated rights and responsibilities, property rights to be more transparent; respect for the rule of law

- greater accountability and financial discipline of the government (the timely return of VAT to companies)

- good labour relations and social dialogue practices.

The European Commission supports this view. In its Communication to the Council and the European Parliament, of 23/10/2001, under the title Towards an internal market without tax obstacles (COM 2001/582 final), the Commission notes that:

Although empirical studies show that there is a correlation between taxation and location decisions, the analysis does not provide evidence of the impact on actual economic decisions. Taxation is, of course, only one of the determinants of investment and financing decisions. The existence and quality of economic infrastructures, the availability of qualified work, as well as the short and medium-term outlook in different markets and countries are among the other important determinants of investment behaviour. The geographical accessibility of markets, transport costs, environmental standards, wage levels, social security systems and the overall attitude of government all play an important role too. Which of these factors are relatively the more important very much depends on the individual type of investment decision. 
Two researchers, Alari Paulus (University of Essex) and Andreas Peichl(University of Cologne), have also questioned in a paper published by the Institute for Social and Economic Research of the University of Essex whether personal income tax reform namely the introduction of a flat personal income tax - is the best instrument to increase growth and employment. Their answer is that:

The user costs of labour and capital play an important role in determining the labour and investment demand. These user costs, however, are determined more by social security contributions and corporate taxes than by personal income tax. ${ }^{8}$

Clearly, a diversity of reasons, rather than a simplistic, singular response, is the key to determining the role that taxation policy might play in generating the growth and employment that all countries need and in meeting their economic, social and environmental policy goals.

\section{References}

Bieling, H-J (2012) 'EU facing the crisis. Social and employment policies in times of tight budgets' Transfer 18(3), ETUI: Brussels.

Matheson, A (2002) 'Better public sector governance: the rationale for budgeting and accounting reform in Western Nations' Models of Public Budgeting and Accounting Reform, OECD Journal on Budgeting Volume 2, Supplement 1, OECD, pp. 37-49.

Theodoropoulou, S and A. Watt (2011) Withdrawal symptoms: an assessment of the austerity packages in Europe ETUI Working Paper 2011.02, ETUI: Brussels.

8 "Effects of flat tax reforms in Western Europe on equity and efficiency" (2008). 